\title{
AP-1 Transcription Factors as Regulators of Immune Responses in Cancer
}

\author{
Vasileios Atsaves ${ }^{1}$, Vasiliki Leventaki ${ }^{2}$, George Z. Rassidakis ${ }^{3,4}$ and Francois X. Claret ${ }^{5, * \mathbb{C}}$ \\ 1 Department of Oncology, Ludwig Institute for Cancer Research-Lausanne Branch, University of Lausanne, \\ Épalinges, 1066 Lausanne, Switzerland \\ 2 Department of Pathology, Children's Hospital of Wisconsin \& Medical College of Wisconsin, \\ Medical College of Winsconsin, Milwaukee, WI 53226, USA \\ 3 Department of Oncology-Pathology, Karolinska Institutet, Karolinska University Hospital, 17176 Stockholm, \\ Sweden \\ 4 Department of Pathology and Cytology, Karolinska University Hospital, 17176 Stockholm, Sweden \\ 5 Department of Systems Biology, The University of Texas-MD Anderson Cancer Center, Houston, TX 77030, \\ USA \\ * Correspondence: fxclaret@mdanderson.org
}

Received: 26 May 2019; Accepted: 15 July 2019; Published: 23 July 2019

\begin{abstract}
Immune check point blockade therapy has revolutionized the standard of cancer treatment and is credited with producing remarkable tumor remissions and increase in overall survival. This unprecedented clinical success however is feasible for a limited number of cancer patients due to resistance occurring before or during a course of immunotherapy, which is often associated with activation of oncogenic signaling pathways, co-inhibitory checkpoints upregulation or expansion of immunosuppressive regulatory T-cells (Tregs) in the tumor microenviroment (TME). Targeted therapy aiming to inactivate a signaling pathway such as the Mitogen Activated Protein Kinases (MAPKs) has recently received a lot of attention due to emerging data from preclinical studies indicating synergy with immune checkpoint blockade therapy. The dimeric transcription factor complex Activator Protein-1 (AP-1) is a group of proteins involved in a wide array of cell processes and a critical regulator of nuclear gene expression during T-cell activation. It is also one of the downstream targets of the MAPK signaling cascade. In this review, we will attempt to unravel the roles of AP-1 in the regulation of anti-tumor immune responses, with a focus on the regulation of immune checkpoints and Tregs, seeking to extract useful insights for more efficacious immunotherapy.
\end{abstract}

Keywords: AP-1; immune checkpoints; PD-1; CTLA-4; PD-L1; immunotherapy; targeted therapy; transcription factors; Tregs

\section{Introduction}

The 2018 Nobel Prize for Physiology or Medicine awarded to the pioneers of immune checkpoint research, James P. Allison and Tasuko Honjo, attests to the considerable advances achieved in the field of immunotherapy over the past decades. Immunotherapy, and more specifically immune checkpoint blockade therapy, represents a transforming event in the treatment of metastatic cancer since for the first time studies have shown that it can promote strong and durable tumor regression in some patients whose tumors have already metastasized [1].

Immune checkpoint blockade (ICB) or immune check point inhibition therapy aims at the inhibition of the molecules collectively known as immune checkpoints, expressed mainly on the cells of the immune system. Immune checkpoints, whose physiological role is to maintain self-tolerance and restrict collateral damage in the tissues following immune responses, are frequently exploited by 
tumor cells to escape from the surveillance of the immune system which leads to immune suppression and promotion of tumor growth [2]. In comparison to conventional treatment modalities in oncology (radiotherapy, chemotherapy etc.), ICB is innovative because it targets molecules expressed on the cells of the immune system, aiming to disrupt the tumor-derived immune suppression and reinvigorate the immune system to elicit a potent and oftentimes durable anti-tumor response. Monoclonal antibodies targeting immune checkpoints (e.g., CTLA-4 and PD-1) have so far received approval from the Food and Drug Administration (and other regulatory authorities) for demonstrating dramatic clinical responses in patients with metastatic cancers, leading to substantial improvement of their overall survival (OS) across diverse histological types and genetics of neoplastic diseases [2,3].

Emerging evidence, however, suggests that ICB is beneficial only for a fraction of cancer patients, while it comes with a great cost of severe immune-related adverse events (irAEs) for a significant portion of those treated [4]. Data from several clinical trials suggest that patients are stratified in the following three groups according to their resistance to ICB therapy: (1) responders, patients who respond to initial treatment and continue to respond, (2) non-responders, those that do not succeed in responding to ICB (primary resistance), and (3) those that initially respond but eventually develop disease progression (acquired or adaptive resistance) $[5,6]$. Several factors have been identified within the TME, such as a genetic and epigenetic mutational load that controls neoantigen processing or presentation by the tumor cells, inhibitory checkpoint expression (e.g., PD-L1) and activation of oncogenic signaling pathways (tumor cell intrinsic mechanism) that suppress the therapeutic effects of ICB by disrupting the functions of tumor-specific cytotoxic T cells [2,7]. In addition, tumor cell extrinsic mechanisms operating outside the TME such indole 2,3-dioxygenase (IDO) activity and the actions of immunosuppressive cells like T regulatory (Tregs) and myeloid-derived suppressor cells (MDSCs), is conducive towards an immunosuppressive environment, promoting tumor growth and resistance to ICB [7].

A growing body of evidence indicate that activation of signaling pathways in various cancer types, such as the Mitogen-Activated Protein Kinases (MAPK) [8], phosphatidylinositol 3-kinase (PI3K) $[9,10]$ and $\mathrm{wnt} / \beta$-catenin [11] can promote an immune-compromised tumor microenvironment, conferring resistance to immunotherapy. Preclinical evidence in various cancer types suggest that MAPK inhibition (MAPKi) can dramatically increase the efficacy of immunotherapy [12-17] mainly via increased antigen presentation from tumor cells, augmented MHC-I expression, suppressed Treg expansion and increased proliferation and activation of tumor-infiltrating cytotoxic T-cells.

Currently, several combinatorial treatment strategies with ICB and MAPKi are under investigation (Table 1, summary of clinical trials) and early results from these clinical trials indicate synergistic inhibition of tumor growth and beneficial effect for patients [18]. For instance, a phase II trial of dabrafenib, trametinib, and nivolumab in BRAF-mutated advanced melanoma patients showed an overall response rate $91 \%$ with relatively small proportion of patients that discontinued the study due to drug toxicity [19]. In a phase III trial (COMBI-I), which evaluated dabrafenib, trametinib and PDR001, an anti-PD-1 antibody, in patients with advanced BRAF-mutated melanoma, preliminary results show that all nine patients responded (33\% complete responses and $67 \%$ partial responses) [20]. Therefore, the initial response rates for combination of targeted therapies with immunotherapy show promising results despite the reported toxicities. Although these studies are promising, the exact players linked to the MAPK inactivation that are responsible for modifying the TME and make it amenable to immunotherapy remain largely elusive. 
Table 1. Ongoing clinical trials with ICB and BRAF (BRAFi) or MEK (MEKi) inhibitors in cancer patients.

\begin{tabular}{|c|c|c|c|c|c|}
\hline $\begin{array}{c}\text { National } \\
\text { Clinical Trials } \\
\text { Identifier }\end{array}$ & Phase & $\begin{array}{l}\text { Targeted Therapy/ } \\
\text { Immunotherapy }\end{array}$ & Institution & Scheduling & Indications \\
\hline NCT02224781 & III & $\begin{array}{c}\mathrm{D}+\mathrm{T}, \text { Ipi }+ \text { Nivo or Ipi }+ \\
\text { Nivo, } \mathrm{D}+\mathrm{T}\end{array}$ & $\begin{array}{l}\text { University of Alabama at } \\
\text { Birmingham Cancer Center }\end{array}$ & Sequential & Melanoma \\
\hline NCT02910700 & II & Nivo + T, with or w/o D & M.D Anderson Cancer Center & Concurrent & Melanoma \\
\hline NCT01940809 & I & $\begin{array}{l}\text { Ipi w and w/o D, T } \\
\text { and/or Nivo }\end{array}$ & Brigham and Women's Hospital & Sequential & Melanoma \\
\hline NCT02130466 & $\mathrm{I} / \mathrm{II}$ & Pembro + T + D & Several locations, USA & Combination & Melanoma \\
\hline NCT02858921 & II & $\mathrm{D}+\mathrm{T}+$ Pembro & Several location, Australia & Sequential & Melanoma \\
\hline NCT02625337 & II & Pembro + D + T & $\begin{array}{l}\text { Antoni van Leeuwenhoek } \\
\text { ziekenhuis Amsterdam, }\end{array}$ & Concurrent & Melanoma \\
\hline NCT03149029 & II & Pembro + D + T & $\begin{array}{l}\text { Beth Israel Deaconess } \\
\text { Medical Center }\end{array}$ & Concurrent & Melanoma \\
\hline NCT02060188 & II & Nivo + Ipi + C & Several locations, USA & Concurrent & Colon Cancer \\
\hline NCT02818023 & I & Pembro + V + C & $\begin{array}{l}\text { UPMC Cancer Center Hillman } \\
\text { Cancer Center }\end{array}$ & Concurrent & Melanoma \\
\hline NCT03273153 & III & Atezo $+C$ & $\begin{array}{l}\text { University of South Alabama; } \\
\text { Mitchell Cancer Institute }\end{array}$ & Concurrent & Melanoma \\
\hline NCT03013491 & $\mathrm{I} / \mathrm{II}$ & CX-072 (anti-PD-L1) + V & Several locations, USA & Concurrent & $\begin{array}{l}\text { Solid tumors } \\
\text { and Lymphoma }\end{array}$ \\
\hline NCT02968303 & II & V + C, Ipi + Nivo & $\begin{array}{l}\text { Several locations, The } \\
\text { Netherlands }\end{array}$ & Sequential & Melanoma \\
\hline
\end{tabular}

Abbreviations: Pembro; pembrolizumab (anti-PD-1), Atezo; atezolizumab (anti-PD-L1), Nivo; Nivolumab (anti-PD-1), Ipi; ipilimumab (anti-CTLA4), CX-072; anti-PD-L1 prodoby, D; dabrafenib (BRAFi), T; trametinib (MEKi), V; vemurafenib (BRAFi), C; Cobimetinib (MEKi).

The Activator protein-1 (AP-1), is a group of transcription factors consisted of four sub-families: the Jun (c-Jun, JunB, JunD), Fos (c-Fos, FosB, Fra1, Fra2), Maf (musculoaponeurotic fibrosarcoma) (c-Maf, MafB, MafA. Mafg/f/k, Nrl), and the ATF-activating transcription factor (ATF2, LRF1/ATF3, BATF, JDP1, JDP2) protein families [21], characterized by pleiotropic effects and a central role in different aspects of the immune system such as T-cell activation, Th differentiation, T-cell anergy and exhaustion [22,23]. MAPK signaling cascade is of paramount importance [24] for regulating AP-1 transcriptional activation and DNA binding activity on a wide array of AP-1 target genes (Figure 1). In the present review, we will be focusing on the specific biologic impact of AP-1 transcription factors on the regulation of immune checkpoints and function of Tregs, both of which can be contributing factors in resistance to ICB. Therefore, a comprehensive description of other important oncogenic functions of AP-1 transcription factors is out of the scope of this article.

AP-1 activity is controlled by the Mitogen Activated Protein Kinases (MAPK), a family of enzymes conserved among eukaryotes that regulate cellular activities in response to numerous environmental signals (e.g., oncogenes, cytokines, growth factors). These signals result in activation of the MAPK pathway via a cascade of phosphorylation events on serine/threonine residues of distinct target proteins, peaking in the activation of the extracellular signal-regulated kinase (ERK), the c-Jun N-terminal kinase (JNK) and the p38 kinase. Inactivation of the pathway is possible by specific pharmacological inhibition of upstream signaling nodes, MAPKKK (MAPK Kinase Kinase) and MAPKK (MAPK Kinase). ERKs (ERK1/2), activate by phosphorylation Elk-1 a transcription factor that belongs to a family classified as a ternary complex factor (TCF). Elk-1 binds the promoter of $c-F O S$ and rapidly induces its expression, contributing to the formation of the transcriptionally active dimers between Fos:Jun, which exhibit high transactivation potential to regulate a wide array of AP-1 target genes. ERKs can also activate JunB transcription by activating Ets-1, an ETS-domain transcription factor that augments the expression of Fos and Jun family members (e.g., JunB) through direct binding on the respective gene promoter. The JNKs, phosphorylate cJun at the transactivation domain (ser63, ser73) and ATF-2 within its N-terminal activation domain (Thr63, Thr71) and thus potentiate the transactivation capacity of these AP-1 members. ATF-2, was also found to be a substrate for p38 kinase, the third member of the MAPK, through phosphorylation at Thr69 and Thr71, which have important implications for its activation. During T-cell activation, TCR/CD28 signaling via PI3K and PLC (generation of $\mathrm{Ca}^{+2}$ through IP3) 
converge to the JNK activation which, in turn, leads to increased AP-1 activity. These transcriptionally active AP-1 components, form cooperative hetero-dimers with the NFAT transcription factor and control the transactivation of key molecules involved in T-cell responses like the IL-2 gene by binding to composite DNA elements. Finally, lack of AP-1 proteins signify that "partnerless" NFAT will bind the target genes with low transactivation potential leading to cell exhaustion or anergy. AP-1 members: cJun, JunB, c-Fos and ATF-2.

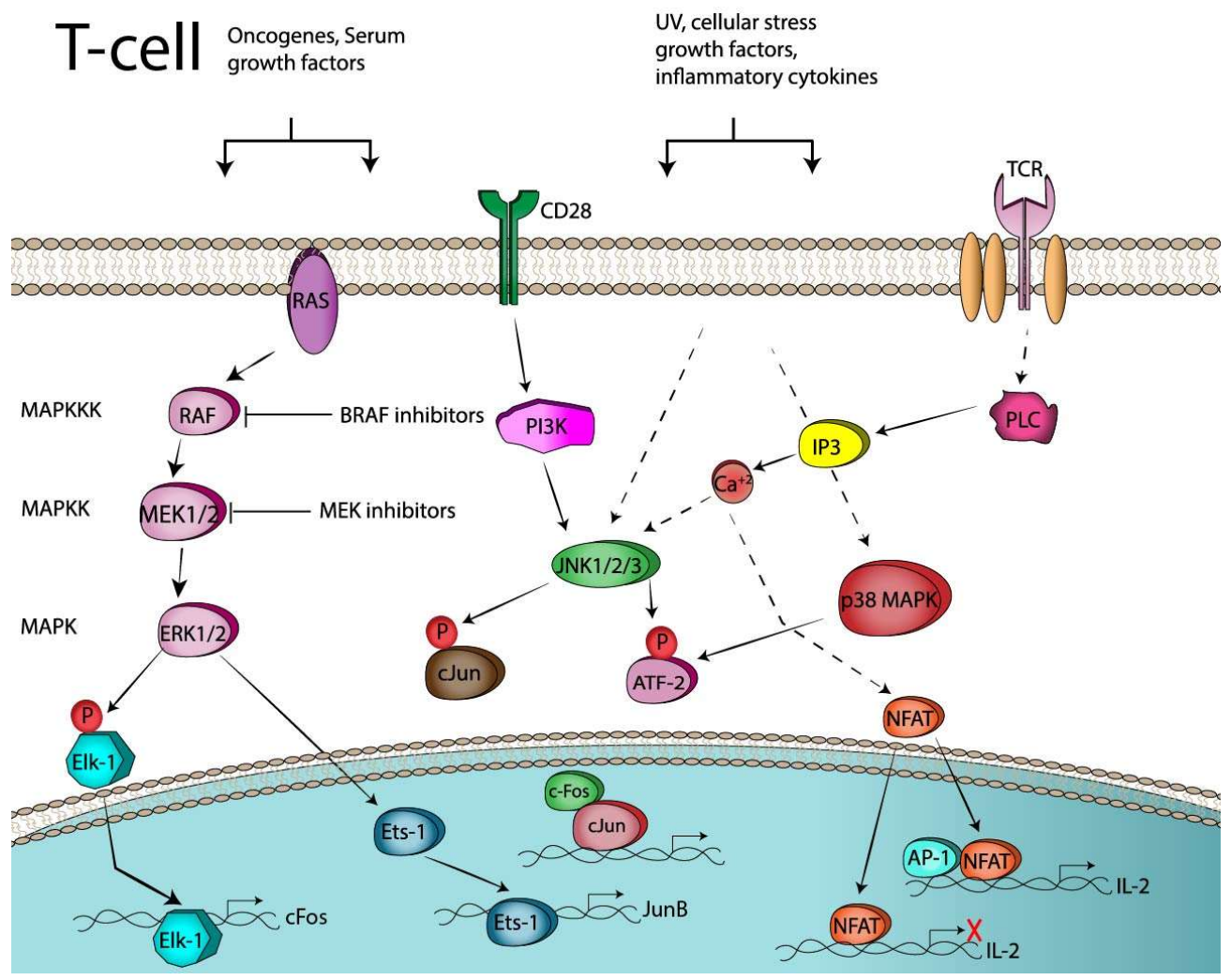

Figure 1. Transcriptional and post-translational activation of AP-1 in T-cells. UV (Ultraviolet); CD28 (co-stimulation, signal-2), TCR (T-cell receptor, signal-1).

\section{Activator Protein-1 (AP-1) Transcription Factors}

It has been more than 30 years since the discovery of activator protein-1 (AP-1), described initially as a DNA-binding protein which recognized a DNA element found in the enhancer region of SV40 and the human Metallothionein IIA gene (MT2A) [25] and characterized by their ability to transactivate target genes upon phorbol ester stimulation (TPA) [26]. These AP-1 transcription factors were later found to regulate a wide range of cellular processes spanning from cell proliferation and survival to tumor transformation, differentiation and apoptosis [21]. AP-1 transcription factors are homo- or hetero-dimmer forming proteins that belong to a group of DNA binding proteins called Basic-Leucine Zipper domain (bZIP) [27]. Dimerization between members of the AP-1 family occurs through a structure which is known as leucine zipper, comprised of a heptad of repeats of leucine residues along a $\alpha$-helix, which can dimerize with another $\alpha$-helix via formation of a coiled-coil structure with contacts between hydrophobic leucine zipper domain. Adjacent to the leucine zipper lies a basic DNA binding domain which is rich in basic amino acids and is responsible for DNA-binding in either 12-O-tetradecanoylphorbol-13-acetate (TPA) response elements (5'-TGAG/CTCA-3') or cAMP response elements (CRE, $5^{\prime}$-TGACGTCA-3') [21,28]. Members of the AP-1 protein family differ markedly in their potential to transactivate AP-1 responsive genes and their ability to form dimmers. For example, the Fos sub-family cannot homodimerize, but they can form stable heterodimers with Jun members $[29,30]$. The Fos and Jun proteins have high transactivation potential, whereas others like JunB, JunD, Fra-1 
and Fra-2 are weaker [31]. Early studies using murine fibroblasts, substantiate the antagonistic nature of some AP-1 members against others. For instance, cJun transcriptional activity is attenuated by JunB and this is due to differences in their activation domains [31,32]. Nevertheless, the current viewpoint suggests that the differential expression of AP-1 components and the cell context of their interactions determines the complex functions of AP-1 transcription factor [27].

\subsection{Regulation of Immune Response by AP-1 in Genetically Modified Mice}

Early studies from transgenic animals implied a prominent role of AP-1 in the regulation of the immune system, arising from targeted overexpression of JunB in T lymphocytes [33]. In these transgenic mice, elevated JunB levels caused upregulation of IL-4 expression, a cytokine which is known for facilitating the differentiation of Th2 cells while preventing the differentiation of Th1 cells. JunB binds to P1 element on IL-4 promoter and synergizes with c-Maf to activate IL-4 luciferase reporter gene and JunB is also preferentially upregulated in developing Th2 cells. Collectively, this study suggests that JunB may contribute to the differentiation of naïve T-helper cells into Th2 during $\mathrm{T}$ cell development. In addition, in vivo data from transgenic mice expressing a mutant variant of cJun (JunAA), which is unable to sustain activation by JNK phosphorylation, reveal that even though T-cell activation and proliferation were not impaired in these mice, c-Jun N-terminal phosphorylation was required for efficient TCR- and TNFa (tumor necrosis factor- $\alpha$ )-induced thymocyte apoptosis, suggesting a role for cJun in thymocyte development [34]. On the other hand, ectopic expression of the FosB2 gene in thymocytes causes aberrant development of T cells and thymic epithelial cells [35].

\subsection{AP-1 and T-Cell Activation}

T-cell activation of naïve T-cells requires two signaling events [36]. The initial signal, signal-1, is generated by interaction of a peptide antigen presented in association with an MHC molecule on the surface of an antigen presenting cell (APC). The supply of a subsequent co-stimulatory second signal (signal-2) which is delivered by interactions of CD28 on the T-cell with molecules on the APC is then required for full T-cell activation and production of cytokines (IL-2), proliferation and differentiation of effector cells [37]. The signaling pathways that are activated by both signals (signal 1 and signal 2) are now well identified [38] and they culminate in the activation of the enzyme phospholipase C (PLC $\gamma$ ), which cleaves the membrane lipid PI(4,5)P2 (phosphatidylinositol 4,5 bisphosphate) producing the second messengers IP3 and DAG (diacylglycerol). The first message, IP3, results in a rapid release of $\mathrm{Ca}^{2+}$ from the ER and this will eventually lead to the activation of the transcription factor, nuclear factor of activated T-cells (NFAT) (Figure 1). Ras, a small G protein which is dependent on GTP for activation, will initiate following TCR engagement the signaling cascade of MAPK which leads to phosphorylation of ERKs (Erk1/2) and the activation of Elk1 by phosphorylation. The latter translocates to the nucleus and binds to the promoter of C-FOS, thus facilitating its transcription (Figure 1) [39]. An additional mechanism contributing to AP- 1 activation from TCR engagement stems again from the MAPKs and the activation of the Jun-N-terminal kinase (JNKs) [40] (Figure 1). The JNKs, phosphorylate cJun, enhancing its transcriptional activity, leading to the formation of the AP-1 complex, Jun:Fos heterodimers, which are transcriptionally potent and thus bind and regulate target genes. cJun in several cancers (melanoma, colon cancer) is also induced through a MAPK independent mechanism, which involves cell-cell contacts and the adhesion molecule E-cadherin [41]. Also, the CD28 pathways via PI3 kinase and acidic sphingomyelinase, can lead to the induction of AP-1 [42]. The effects of the AP-1 transcription factors, associated with the immune system, are largely mediated through combinatorial regulation with the NFAT, a calcium/calcineurin pathway-dependent transcription factor. The transcription factors of the NFAT family are key regulators of $\mathrm{T}$ cell activation [43]. There are five members in the NFAT family members, of which NFAT1-4 (NFATc1-c4) are regulated by $\mathrm{Ca}^{2+}$-calcineurin signaling. NFAT/AP-1 transcription factors bind cooperatively to composite DNA sites, where they participate in the formation of stable ternary complexes regulating the expression of target genes (Figure 1). Composite DNA sites have been identified on the promoters of most of the cytokine genes, including 
IL-2, IFN- $g$, TNF- $a$, GM-CSF, IL-4, FasL, CD25 and NFAT/AP-1 where combinatorial regulation has been well documented [44]. DNA-binding experiments have demonstrated that the NFAT/AP-1-binding complex contains predominantly cJun, c-Fos, JunB and Fra-1 proteins [45].

\subsection{AP-1 and T-Cell Anergy or Exhaustion}

T-cell "anergy" is an unresponsive state of T-cells in which T-cells are activated in the absence of a positive costimulatory signal, while T-cell "exhaustion" is referred to the state of $\mathrm{CD} 8^{+} \mathrm{T}$ cells that respond poorly because of prolonged antigen exposure during chronic viral infections or cancer [46,47]. Some of the hallmarks of anergic $\mathrm{T}$ cells are the inhibition of proliferation and their inability to synthesize IL-2 in response to TCR engagement [46]. Similarly, exhausted CD8 ${ }^{+} \mathrm{T}$ cells display a transcriptional program distinct from that of functional effector or memory $\mathrm{CD} 8^{+} \mathrm{T}$ cells, characterized by the expression of inhibitory cell-surface receptors, including PD-1, LAG-3, TIM-3, TIGIT, and CTLA-4, and by impaired IL-2, TNF, and IFN- $\gamma$ cytokine production. NFAT and AP-1 transcription factors synergistically play a central role in inducing hyporesponsive states, such as anergy and exhaustion [48,49]. Exhausted cells exhibit low expression of AP-1 factors (Fos, Fosb, and Junb) [50]. In addition, several lines of evidence suggest that cooperation of NFAT with AP-1 stimulates gene expression after immune response while absence of AP-1 leads to repression of the involved genes and to blockade of T-cell activation and proliferation, which eventually leads to T-cell anergy [51,52]. NFAT, in the absence of cooperation with the transcription factor AP-1 (Fos-Jun), fosters a transcriptional program of genes associated with anergy and exhaustion in both $\mathrm{CD}^{+}$and CD8 $\mathrm{T}$ cells, whereas, when AP-1 factors are present, NFAT drives expression of molecules such as cytokines that are involved in effector responses [48].

Collectively, these findings indicate that the presence or absence of AP-1 in the transcriptional complexes with NFAT contributes greatly to the anergy/exhaustion phenotype of T-cells, reversal of which is an important clinical goal as demonstrated by the immune checkpoint blockade therapy. Therefore, targeting the AP-1:NFAT complexes might have therapeutic implications. Indeed in a recent study, Mognol et al. designed a FRET-based high-throughput screen to identify compounds that disrupt the NFAT:AP-1:DNA complex. They identified a small molecule, which disrupts the NFAT:AP-1 interaction at the composite antigen-receptor response element- 2 site without affecting the binding of NFAT or AP-1 alone to DNA. This small molecule is capable of binding to DNA in a sequence-selective manner and inhibit the transcription of the IL2 gene and several other cyclosporin A-sensitive cytokine genes important for the effector immune response thus providing a proof-of-concept approach to target AP-1 transcription factors [53].

\section{AP-1 and Immune Checkpoint Regulation}

According to the two-signal model, co-stimulatory molecules are responsible for sustained T-cell activation and effector T-cell function. Evidence for the two-signal model of T-cell activation was provided by the discovery of CD28 on T-cells, as the archetypal co-stimulatory molecule, which after binding to its ligand, it provides signal-2 stimulation, which along with TCR signal- 1 is required for full T-cell activation. Subsequent discovery of CTLA-4 as an antagonistic molecule to the CD28 function, provided feedback for the negative stimulation of T-cells following activation and designated a group of molecules with similar function as co-inhibitory molecules. Ever since, the list of co-stimulatory and co-inhibitory molecules and their ligands is exponentially increasing along with potential clinical applications in patients with more than 10 cancer types, including metastatic melanoma, renal cell carcinoma, non-small-cell lung carcinoma (NSCLC), Hodgkin's lymphoma and several others [54-56]. Signaling downstream the immune checkpoint molecules is complex and has been reviewed in great extent elsewhere [57], but there is evidence for the participation of several members of the AP-1 family [57]. 


\subsection{Co-Stimulatory Molecules and AP-1 Transcription Factors}

\subsubsection{CD28}

CD28, a 44-kDa type I transmembrane glycoprotein, is constitutively present on the surface of naïve and activated T-cells [58]. Stimulation via the CD28 pathway augments lymphokine production and proliferation in T cells while preventing induction of anergy [57]. Inactivation of CD28 in vivo gives rise to immune compromised mice, characterized by impaired T-cell responses to antigen and defects in T-cell differentiation [59]. The natural ligands for CD28 are the B7 family of adhesion proteins present on dendritic cells, activated B cells, and macrophages. Ligation of CD28 on T-cells with members of the B7 (CD80 or D86) family on antigen presenting cells provides signal-2. CD28 harbors a YMNM motif in his cytoplasmic tail through which it associates with the p85 subunit of PI3K, a common signaling intermediate, to initiate targeting of AKT (also known as protein kinase B (PKB)) that subsequently results in activation of several distal molecules. Co-stimulatory signals from CD28 ligation results in augmentation of downstream effector cascades, like the PI3 kinase, Ras and acidic sphingomyelinase [57]. These pathways result in the activation of transcription factors such as NF- $\mathrm{KB}$ and AP-1, which mediate functional outcomes including IL-2 production and T cell survival [22,45].

Insights for AP-1 involvement in CD28 pathway, comes from in vitro [42,60] and in vivo [61] studies, after CD28 co-stimulation. In part, stimulation of AP-1 activity is a result of JNK activation, which can occur through both TCR/CD3 and CD28 pathways, resulting in higher levels of JNK activity compared with signal 1 stimulation alone [62]. In a study using T-cell blasts, investigators were able to observe the result of CD28 signaling in isolation without the TCR contribution. They found that CD28 costimulation induced AP-1 activity, which was dependent on PI3K and partly the acidic sphingomyelinase [42]. Also c-jun mRNA induction was reported in T-cells after cross-linking of CD28. This CD28-dependent induction of c-jun expression requires protein tyrosine kinase activity but is $\mathrm{Ca}^{2+}$ independent [63]. Interestingly, CD28 also recruits the RAS guanine nucleotide exchange factor (GEF) RAS guanyl nucleotide-releasing protein (RASGRP) to the T cell-APC interface to induce activation of RAS and the downstream phosphorylation of AKT, JNKs and ERKs which are potent inducers of the AP-1 activity [64]. Finally, CD28 engagement with B7 ligand, augments JNK signaling, which in turn regulates Elk-1 transactivation at the $c-F O S$ gene to promote AP-1 complexes which are important to IL-2 gene expression [65].

\subsubsection{CD40/CD40L}

The costimulatory receptor CD40 is a member of the tumor necrosis factor receptor (TNFR) superfamily. CD40 is expressed on dendritic cells, B cells, macrophages and also on non-hematopoietic cells, like endothelial cells and epithelial cells [66]. CD40 binds to its ligand CD40L (or CD154), a type II transmembrane protein, which is transiently expressed primarily on the surface of activated B and T-cells and other non-immune cells [67]. The wide expression pattern of CD40 and its ligand suggests a pivotal role in the regulation of immune-related processes [67]. Ligation of CD40 results in clustering of CD40 and facilitates the recruitment of the TNFR associated factors (TRAFs) to the cytoplasmic domain of CD40 [68]. The TRAFs then activate several signaling pathways including the NFKB, the MAPKs, PI3K, as well as the phospholipase $\mathrm{C} \gamma(\mathrm{PLC} \gamma)$ pathway [68]. TRAF2 and TRAF3 are involved in activation of the JNK pathway.

In human urothelial cells, engagement of the CD40 to membrane presented CD40L led to CD40-induced apoptosis involving TRAF3 and JNK/AP-1 activation [69]. Furthermore, the murine CD40L promoter contains NFAT binding motifs which require AP-1 cooperational binding for activation of transcription [70]. In biliary epithelial cells, ligation of CD40 with the recombinant CD40L promoted Fas-dependent apoptosis and nuclear factor $\kappa B(\mathrm{NF}-\mathrm{kB}) / \mathrm{AP}-1$ signaling. Sustained activation of AP-1 in the absence of NF- $\mathrm{KB}$ signaling may be critical in determining the outcome of CD40 engagement [71]. Besides, in B-lymphocytes, AP-1 proteins were found to control the mouse IL-6 expression after CD40 engagement, since mutations in the putative AP-1 (and C/EBP) binding sites on the murine IL-6 
promoter, abrogated promoter transcriptional activity. In the same study, CD40 stimulation led to phosphorylation of c-Jun on its activation domain, implicating CD40-mediated Jun kinase activation in the transcriptional regulation of IL-6 production [72]. Another study, also in B cells, has demonstrated that stimulation through both CD40 and Toll-like receptor 7 (TLR7) enhanced the production of cytokines through increased JNK signaling and AP-1 activity. The increased level of active JNK in dual-stimulated cells was accompanied by an increase in the level of active AP-1 monomers cJun and cFos [73]. Moreover, in cultured human fetal microglia cells, ligation of CD40 with soluble trimeric CD40L, results in augmentation of IL-8 (CXCL8) expression and this is mediated by activation of the ERK1/2 MAPK pathway. Gel shift analyses demonstrated that NFKB and AP-1, but not C/EBP $\beta$ mediate microglial CXCL8 production [74].

\subsubsection{ICOS/4-1BB}

In contrast to the constitutively expressed CD28, the inducible $\mathrm{T}$ cell co-stimulator (ICOS) has to be de novo induced on the T-cells [75]. ICOS shares several features with CD28 including a YMXM motif in its cytoplasmic tail that associates with p85 of PI3K [76]. ICOS cannot induce IL-2 gene transcription as efficiently as CD28 and this has been attributed in part to the inability of the YxxM motif of ICOS to associate with Grb2 [38]. ICOS promotes the expansion of several T helper subsets (Th1, Th2, Th17 subsets) and regulatory Treg cells in a context-dependent fashion [57]. AP-1 is involved in ICOS gene expression downstream of TCR/CD28 signaling. An AP-1 binding site was identified on the ICOS promoter and previous studies demonstrate that AP-1 binding occurs upon TCR/CD28 stimulation. Moreover, ectopic expression of Fra2 and other AP-1 molecules upregulated ICOS expression on T cells [77].

4-1BB (CD137) is a member of the TNFR superfamily and is responsible for co-stimulation of T-cell responses by interaction with 4-1BB ligand expressed on APC. The expression of 4-1BB has been known to be dependent on $\mathrm{T}$ cell activation. Cross-linking of 4-1BB with its ligand, 4-1BBL, promotes IL-2 production, differentiation and proliferation of T-cells while protecting against activation-induced cell death (AICD) of T-cells [78]. Following TCR-stimulation, Kim et al. showed that 4-1BB expression is regulated by the NF- $\mathrm{KB}$ and AP-1 transcription factors. By a combination of methods, they identified NF- $\mathrm{KB}$ and AP-1 as crucial transcriptional complexes driving 4-1BB transcription and discovered that MEK and JNK1 uncompromised function is required for activation-dependent 4-1BB upregulation [78]. Finally, regulatory AP-1 responsive elements have been found on the promoter of the mouse 4-1BB gene, suggesting a conserved role for AP-1 among species [79,80].

\subsection{Co-Inhibitory Molecules}

\subsubsection{PD-1}

Programmed cell death protein-1 (PD-1), also known as CD279, is a type I transmembrane protein, whose expression is induced on activated immune cells such as T, B and NK cells. The major role of PD-1, in contrast to the CTLA-4, is to restrict the T-cell activation in peripheral tissues, to prevent from autoimmune disease and to maintain tolerance within the TME [2]. The cytoplasmic domain of PD-1 contains an immunoreceptor tyrosine-based inhibitory motif (ITIM) and an immunoreceptor tyrosine-based switch motif (ITSM) which are speculated to have immunosuppressive properties [81]. In the direct pathway, binding of PD-1 to its ligand, the B7 member PD-L1, strongly interferes with TCR/CD28 signal transduction and terminates ZAP70 and PI3K phosphorylation by recruiting the SHP1 and SHP2 phosphatases to its tyrosine phosphorylated ITIM and ITSM motifs [82,83]. As a result, PD-1 abrogates cytokine production, causes cell cycle arrest and decreases transcription of the pro-survival factor Bcl- $\mathrm{X}_{\mathrm{L}}$ [81]. Also, $\mathrm{PD}-1$ inhibits RAS and, subsequently, its downstream targets ERK1 and ERK2 through an SHP1- and SHP2-independent mechanism [57,81]. Because PD-1 is also highly expressed in Tregs where it regulates the development, maintenance, and function of induced regulatory T cells [84], it makes it an ideal target for ICB, since PD-1 inhibition could also interfere with 
their function on the proliferation on the TME [84].Therefore, PD-1 blockade could theoretically not only lead to enhancement of the activity of effector T cells and NK cells in the peripheral tissues but also to the restriction of the immunosuppressive action of Tregs in the TME [2].

A study revealed that a major role of PD-1 is interfering with the AP-1 signaling generated from co-stimulatory cascades. PD-1 inhibits T-cells function by augmenting BATF expression. Accordingly, ectopic expression of BATF was sufficient to impair $\mathrm{T}$ cell proliferation and cytokine secretion, whereas BATF knockdown reduced PD-1 inhibition. Silencing BATF in T cells from individuals with chronic viremia rescued HIV-specific $\mathrm{T}$ cell function. PD-1, through BATF upregulation, activated a program of genes specific for exhausted CD8 ${ }^{+}$T-cells, although the details of this molecular mechanism still remains elusive [85]. In another study using a mouse model, tumor infiltrating T-cells exhibited high AP-1 activity and specifically expression of c-fos was shown to upregulate PD-1 in tumor infiltrating T-cells during tumor progression. Forced expression of c-fos in T-cells was associated with higher tumor burden, while T-cell specific depletion of c-fos led to reduction in tumor volume. C-fos was found to bind to the promoter region of $P D-1$ and thus facilitates its expression. Therefore, blockade of c-fos mediated induction of PD-1 could be harnessed therapeutically to restore T-cells anti-tumor response [86].

\subsubsection{PD-L1}

PD-L1 (CD274), one of the two ligands for PD-1, is a member of the B7 family of co-inhibitory molecules that negatively regulates T-cell immune responses. PD-L1 has a broad expression pattern and it is expressed in normal tissues (T and B cells, NK cells, macrophages, dendritic cells, epithelial cells, and vascular endothelial cells) and tumor cells [87]. Specifically, ligation of PD-L1 of cancer cells to PD-1 expressed on T cells suppresses T-cell activation, proliferation, and induces T-cell apoptosis, which renders it an excellent target for ICB, using antibodies against PD-L1. The regulation of PD-L1 is complex and it occurs at the genetic, transcriptional and post-transcriptional levels [88] and discussing it would be beyond the scope of this review.

In Hodgkin's Lymphoma (HL), which is characterized by constitutive AP-1 activity [89], AP-1 response elements were identified and demonstrate that cJun and JunB bind to an enhancer region of the PD-L1 promoter, facilitating the PD-L1 expression along with Epstein-Barr virus (EBV) infection [90]. Also in another EBV-associated tumor, the nasopharyngeal carcinoma (NPC), the EBV-induced latent membrane protein 1 (LMP1) and IFN $\gamma$, upregulated PD-L1 expression through AP-1, STAT3 and NF- $\mathrm{KB}$ pathways. These findings imply that blocking both the AP-1 oncogenic pathway and PD-1/PD-L1 checkpoints may be a promising therapeutic approach for EBV positive NPC tumors [91].

In melanoma, PD-L1 is highly expressed in cell lines resistant to BRAF inhibitors (BRAFi). BRAFi-resistant cell lines developed dramatic activation in MAPK signaling pathways including extracellular signal-regulated kinase (ERK1/2), JNKs and p38. Increased activation of MAPK promotes PD-L1 expression in the BRAFi-resistant melanoma cells, associated with increased activity of c-Jun. Conversely, inhibition of c-Jun expression by siRNA led to significant decrease of PD-L1 in K028 resistant and parental M34 line, as well as near complete inhibition of PD-L1 expression in M34-resistant line. Thus, c-Jun promotes PD-L1 expression, which can be enhanced via cooperation of STAT3 in melanoma cells. These findings have important therapeutic implications for combining targeted treatment with immune modulation to improve antitumor responses and patient outcomes [92].

In lung adenocarcinoma, MEK inhibition led to a marked reduction on surface PD-L1 levels in vitro, and similar results were seen after ERK2 gene silencing. Moreover, the $P D-L 1$ promoter was found to contain a functional AP-1 binding site, whose activity is abrogated by MEKi and cJun was bound to this AP-1 site. Overall, the study points to the seminal role of AP-1 in regulating PD-L1 expression, through MAPK upstream signaling [93].

In a mouse model of chronic lymphocytic choriomeningitis virus (LCMV) infection, PD-1 blockade resulted in reinvigoration of exhausted T-cells $\left(\mathrm{T}_{\mathrm{EX}}\right)$ but these changes were not accompanied by memory development and $\mathrm{T}_{\mathrm{EX}}$ become again re-exhausted upon repeated antigen stimulation. The 
authors hypothesized that the genome-wide epigenetic landscape of $\mathrm{T}_{\mathrm{EX}}$ may contribute to the lack of durable improvements after PD-L1 checkpoint blockade. Thus, they performed global chromatin landscape mapping using assay for transposase-accessible chromatin with high-throughput sequencing (ATAC-seq). They found that anti-PD-L1 treatment caused transcriptional rewiring and reengagement of effector circuitry in the $\mathrm{T}_{\mathrm{EX}}$ epigenetic landscape. Motif enrichment analysis of the few differentially accessible regions suggested that cells from anti-PD-L1-treated mice augmented activity of NF- $\mathrm{KB}$, AP-1, and IRF family members but decreased activity of NFAT, Egr2, and Nur77. This study illustrates that AP-1 transcription factors constitute important players in the transcriptional circuitry of re-energized $\mathrm{T}_{\mathrm{EX}}$ after anti-PD-L1 blockade. [94].

\subsubsection{CTLA-4}

CTLA-4, a member of the immunoglobulin family, is a CD28 homolog that has higher affinity for B7 ligands [95] and therefore antagonistic actions to CD28. Unlike CD28, which is constitutively expressed on the surface T-cells, CTLA4 is immediately upregulated following TCR engagement (signal-1), with an expression peak, 2 to 3 days after activation [3]. The central role of CTLA4 for keeping $\mathrm{T}$ cell activation in check was highlighted from studies with genetically modified mice that are deficient for CTLA-4, which are characterized by profound immune dysregulation and autoimmune disease [96]. It is thus believed that CTLA-4 provides the regulatory braking in proportion to the acceleration received from CD28 and, in contrast to PD-1/PD-L1 axis which function at the peripheral tissues and tumor site, CTLA-4 is regarded as a negative regulator of T-cell function at the site of T-cell priming when naïve T-cells are primed when they are engaged with the peptide-MHC-APC. The inhibitory mechanisms employed by CTLA-4 signals include the recruitment of protein phosphatases, SHP2 and PP2A, which are essential in dampening kinase signals that are induced by TCR/CD28, sequestration of CD80 and CD86 from CD28 engagement as well as active removal of CD80 and CD86 from the APC cell surface [2,97]. Apart from controlling the activation status of CD8 ${ }^{+}$effector cells, there is evidence suggesting that CTLA-4 is necessary for the optimal function of Tregs [98] since CTLA-4 is constitutively expressed in Tregs [99]. Treg cell-specific genetic ablation of CTLA4 or blockade with anti-CTLA-4 antibody significantly compromise their ability to regulate both autoimmunity and antitumor immune response [98,100]. Therefore, it is considered that factors contributing to the mechanism of CTLA-4 blockade are the augmentation of both effector $\mathrm{CD} 8^{+} \mathrm{T}$ cell activity and downregulation of Treg cell-dependent immunosuppression [2]. CTLA-4 turns off activation of downstream TCR/CD28 signaling events by inactivation of ERK and JNK pathways, without affecting phosphorylation of TCR-zeta and ZAP70. However, AP-1 activity of these anti-CTLA-4 treated T-cells was not reported in that study [101].

A subsequent study in mouse $\mathrm{CD} 4^{+} \mathrm{T}$ cell blasts illustrated that the suppressive effect exerted by CTLA4 (e.g., on the reduced production of IL-2) is upon inhibiting the signaling delivered through $\mathrm{CD} 28$ ligation. Since, $\mathrm{CD} 28$ ligation leads to increased transcriptional activity of AP-1 and NF- $\mathrm{kB}$, it was shown that CTLA-4 co-ligation markedly decreased the AP- 1 activity on activated T-cells [102]. Findings from another study corroborated the AP-1 role in the immune suppressive function of CTLA-4 ligation, since in $\mathrm{CD} 3 / \mathrm{CD} 28 \mathrm{mAb}$ activated mouse $\mathrm{CD} 4^{+} \mathrm{T}$-cells, following ligation of CTLA-4, AP-1 and NFAT transcriptional activity was obliterated in a very rapid manner (10 hours after activation). CTLA- 4 cross linking on activated cells completely blocked AP-1 and NFAT transcription factors before any effects on $\mathrm{T}$ cell proliferation could be observed and importantly they reported that the effect was independent of CD28 co-stimulation, suggesting that CTLA-4 inhibits the TCR signaling cascade [103].

\subsubsection{Tregs}

Regulatory cells (Tregs) is a population of $\mathrm{CD} 4^{+} \mathrm{T}$ cells that are characterized by the expression of CD25 and the forkhead transcription factor FOXP3 [104,105]. They are also anergic, meaning they don't produce IL-2 or other effector cytokines such as IFN $\gamma$. Lastly, they suppress the immune response of the effector T cells by producing inhibitory factors, such as TGF $\beta$, IL-10 and IL-35. The 
central role of Tregs is to prevent the excessive activation of immune cells, which would otherwise damage the host but also to suppress anti-tumor immune response. For example, mutations of the gene encoding the Treg-specific transcription factor FOXP3, impaired Treg cell development and caused a fatal multi-organ autoimmune disease called immune dysregulation, polyendocrinopathy, enteropathy, and X-linked (IPEX) syndrome [106]. Depletion of CD $4^{+} \mathrm{CD} 25^{+} \mathrm{FOXP3}{ }^{+}$Treg cells by a variety of methods is also able to cause similar autoimmune diseases in otherwise normal rodents [107]. Infiltration of a large number of Treg cells into tumor tissues is often associated with poor prognosis. There is accumulating evidence that the removal of Treg cells is able to evoke and enhance anti-tumor immune response [107].

Mantel et al. using a combination of techniques in primary human T-cells, have dissected and functionally analyzed the FOXP3 promoter. The analysis revealed that the basal promoter contains six NFAT and AP-1 binding sites, which are positively regulating the transactivation of the FOXP3 promoter after triggering of the TCR [108]. Two regulatory enhancer regions on the FOXP3 locus, termed the conserved noncoding sequences (CNS) I and II (or Enhancer I and II) were found to control the induction and maintenance of FOXP3 gene expression. In a more recent study, investigators proposed that AP-1 and other factors control Enhancer 2 activity of the FOXP3 promoter in Tregs [109].

In naturally occurring Tregs when stimulated with anti-CD3/CD28, FOXP3 was found to maintain the unresponsive state of Tregs by dampening the DNA binding activity of AP-1 transcription factors. Co-immunoprecipitation studies using HEK293 cells indicate that FOXP3 suppresses AP-1 transcriptional activity by interacting with c-Jun. Importantly, JNK-mediated phosphorylation of c-Jun is required for c-Jun and FOXP3 interaction. In addition, FOXP3 also interacts with c-Fos, but not JunB and ATF-2. Finally, inhibition of FOXP3 expression by siRNA in Tregs, restored both AP-1 DNA-binding and the proliferation of Tregs. These data point to a prominent role of FOXP3-AP1-orchestrated regulation of unresponsiveness in Tregs [110].

Another study in a sepsis model of Tregs confirmed that JNK/AP-1 signaling cascade contributes to the elevated expression of FOXP3 and controls FOXP3 promoter activity. Specifically, c-Jun and c-Fos bind to FOXP3 promoter, fostering its transcription in Tregs. Accordingly, siRNA treatment of Tregs against AP-1 components, c-Fos, Fra-2, c-Jun or JunD, decreased the expression of FOXP3. Of note, pharmacological inhibition the JNK pathway also reduced FOXPp3 protein levels [111]

TGF- $\beta$ is an important contributing growth factor for Treg differentiation and function and has the ability to induce the expression of FOXP3 in $\mathrm{CD}^{+} \mathrm{CD} 25^{-}$human $\mathrm{T}$ cells [112]. In one study investigators used $\mathrm{CD}^{+}$cells from gene targeted FOXP3-IRES-GFP mice, that were previously stimulated with anti-CD3/CD28 ${ }^{+}$TGF- $\beta$ and showed that JNK inhibition led to a marked decrease of FOXP3, suggesting that the TGF- $\beta$ induction of FOXP3 is MAPK-dependent. Moreover, a previously known AP-1 site on the enhancer of FOXP3 promoter was identified to be a major contributor of the TGF- $\beta$-induced FOXP3 transcriptional activity. In addition, deletion of the AP-1 site in the enhancer of FOXP3 promoter, greatly decreased FOXP3 promoter-enhancer activity. Moreover, treatment of anti-CD3/CD28/TGF- $\beta$ stimulated $\mathrm{CD}^{+} \mathrm{T}$ cells with a JNK inhibitor resulted in attenuation of Smad3 binding to enhancer I as determined by ChIP analysis. Taken together, these data indicate that there is control of FOXP3 transcription exerted by AP-1 either directly (e.g., by direct binding of NFAT/AP-1 complexes on FOXP3) or by indirect effects involving the ability of NFAT-AP-1 to regulate the binding of pSmad 3 to an adjacent enhancer I site on the FOXP3 locus [113].

The basic leucine zipper transcription factor ATF-like 3 (Batf3) is a member of the AP-1 transcription factor family. Accumulative evidence supports the notion that Batf3 is a key player in Treg differentiation. Specifically, Lee et al. showed that Batf3 is preferentially expressed in effector CD4 ${ }^{+} \mathrm{T}$ cells and not in Tregs, while it inhibited the differentiation of regulatory $\mathrm{T}$ cells in the periphery. Consistently, overexpression of Batf3 in activated naïve $\mathrm{CD}^{+}$cells inhibited FOXP3 induction. CD4-specific knock out of Batf3 led to favourable differentiation into Tregs in vitro and in colonic lamina propria. Importantly, mice lacking Batf3 showed enhanced Treg function in gut-associated immune disease models. Finally, Batf3 protein was co-precipitated with chromatin from the CNS1 region of the FOXP3 
locus, indicating physical interaction and thereby attenuating gene transcription. Thus, Batf3 is a transcriptional suppressor of Treg differentiation [114]

Another study addressed the role of Batf in Treg biology, by generating strains of mice carrying specific mutant FOXP3 alleles, that were previously identified in human patients with autoimmune disease driven by globally compromising Treg cell physiology. It was found that a specific FOXP3 mutation perturbed FOXP3 interactions with Batf by broadening its DNA-binding specificity and induced a distinctive pattern of tissue-restricted inflammation by impairing Treg cell function in certain non-lymphoid tissues. These findings identify Batf as a critical regulator of tissue Treg cell homeostasis [115]

OX40 is a co-stimulatory molecule of the TNFR superfamily, whose expression is rapidly induced by T-cell activation. OX40 costimulation plays a critical role in cell survival, proliferation, and generation of memory cells [116]. Zhang et al. employed naive $\mathrm{CD}^{+} \mathrm{T}$ cells activated under iTreg-polarizing conditions with or without OX40 engagement. They showed that OX40 co-stimulation can regulate the differentiation of Tregs, by inhibiting FOXP3 expression and induction of Tregs partly via the AP-1 transcription factor batf3 [117]. They demonstrate that in OX40-stimulated cells, BATF3 and BATF were among a cohort of genes to be highly upregulated. Moreover, upon OX40 ligation in induced Tregs, ChIP assays identified that BATF3/BATF can physically bind to FOXP3 promoter and through recruitment of Sirt1/7, they produced a closed chromatin configuration at FOXP3 locus. Thus, targeting OX40 costimulation could have important therapeutic implications [117].

A recent study has documented that the AP-1 protein JunB, is expressed in effector Treg (eTreg) cells and is required for eTreg-mediated immune homeostasis through promotion of an interferon regulatory factor 4 (IRF4)-dependent transcription program [118]. In this study investigators showed that mice lacking JunB in Treg cells develop multi-organ autoimmunity, concomitant with aberrant activation of T helper cells. Moreover, they demonstrate that JunB promotes expression of Treg effector molecules, such as ICOS and CTLA4, in BATF-dependent and BATF-independent manners while it is required for homeostasis and suppressive functions of eTreg. Mechanistically, JunB facilitates the accumulation of IRF4 at a subset of IRF4 target sites, including those located near ICOS and CTLA4. Therefore, this study highlights JunB as a critical regulator of Treg-mediated immune homeostasis [118].

\section{Conclusions}

AP-1 components (c-Jun, JunB, c-Fos, Batf) were found to transcriptionally induce the expression of genes encoding for co-inhibitory immune checkpoints (PD-1, PD-L1) via binding on the enhancer regions of the respective gene promoter. On the other hand, studies have demonstrate the ability of AP-1 proteins to bind on FOXP3 gene locus and promote the expression of this master regulator of Treg identity (Figure 2). Moreover, consistent with a highly context specific and dimerization partner dependent role of AP-1, revisited preclinical data imply differential functions of AP-1 members in Treg physiology, as Batf3 [114] suppresses Treg differentiation while JunB [118] and BatfF [115] appear to positively regulate Treg homeostasis and function. Interestingly, AP-1 complexes seem to participate in the transcriptional circuitry rewiring of exhausted T-cells reinvigoration after ICB, which renders them possible downstream targets of ICB therapy. It is noteworthy that several of these AP-1 related functions responsible for increased inhibitory immune checkpoints expression or Tregs function, were found to be MAPK-dependent [92,93,113], suggesting that they could be attenuated by pathway-specific MAPK inhibitors. Moreover, besides pharmacological inhibition of MAPK, one could speculate that selective depletion of specific AP-1 components (e.g., via siRNA or crisp genetic ablation or novel small molecules) could remove the inhibitory braking exerted by co-inhibitory checkpoints (e.g., PD-1/PD-L1) or impair the immunosuppressive Tregs and thus restore the effective anti-tumor T-cell responses and synergistically augment the efficacy of immunotherapy. As a matter of fact, AP-1 inhibition would be even more advantageous because, in addition to their effects on immune response, they also exert strong tumor growth and survival activity. Unfortunately, AP-1 transcription factors are also crucial in the initial TCR/CD28 downstream cascade which leads 
to full T-cell activation and is therefore very likely that AP-1 inactivation could undermine the T cell responses that immunotherapy seeks to harness. Much anticipated results from ongoing clinical trials with combinatorial treatments (MAPKi/ICB) might provide some insights on the mechanism of the synergistic effects in cancer patients and whether the AP-1 transcription factors are important mediators. Although more studies are required to elucidate the exact role of this complex family of transcription factors (AP-1) in the regulation of T-cell responses, it is becoming clear that like a delicate balance, AP-1 transcription factors have an impact on both the co-stimulatory and co-inhibitory aspects of T-cell responses (Table 2). Therefore, careful modification of these AP-1 signals could determine the outcome of effector anti-tumor T-cell responses and potentiate the beneficial role of immunotherapy in tumor regression.

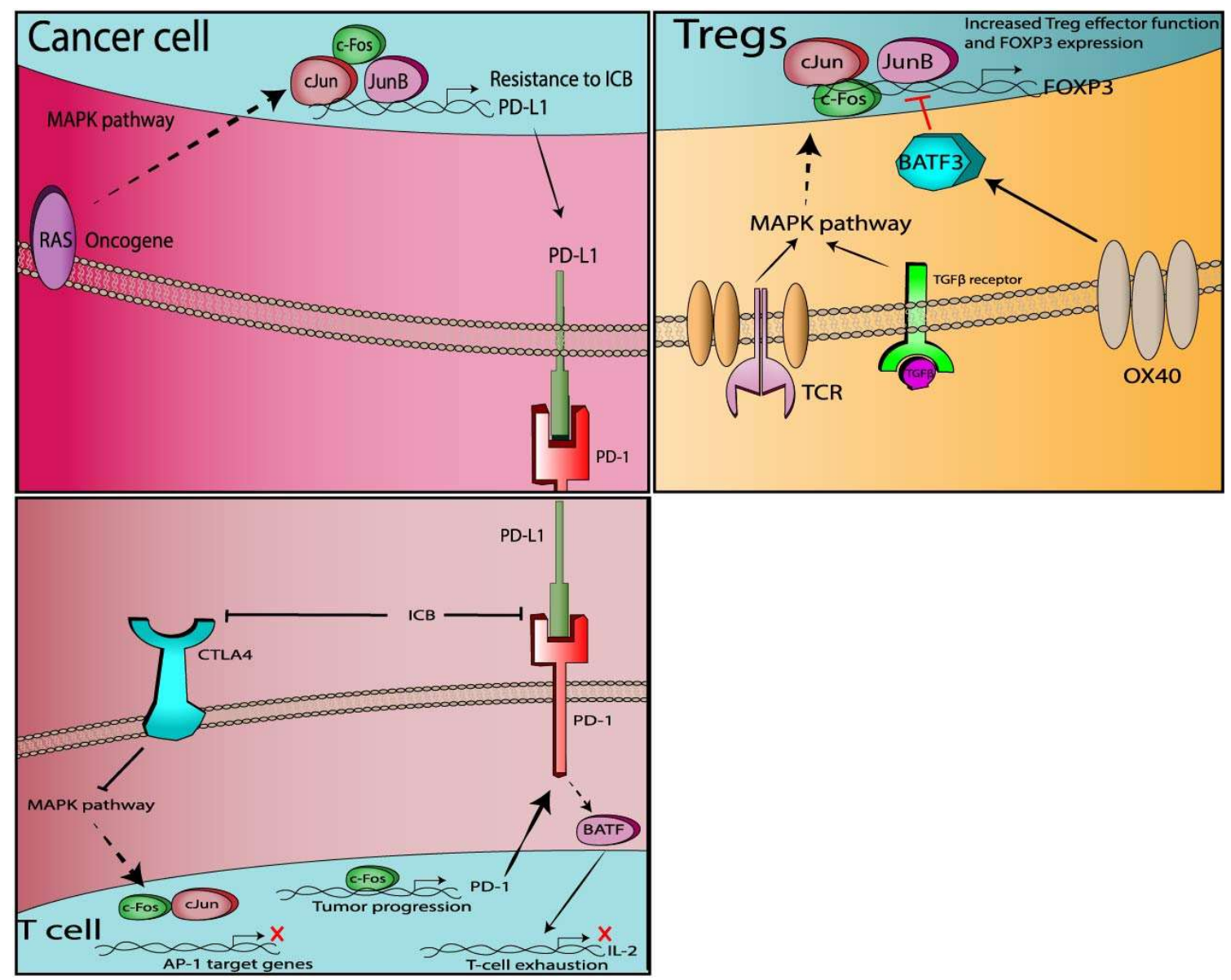

Figure 2. AP-1-dependent regulation of immune checkpoints. 
Table 2. Summary of AP-1 interactions in T-cell immune responses.

\begin{tabular}{|c|c|c|c|c|c|c|}
\hline Gene Name & $\begin{array}{l}\text { Direction of the } \\
\text { Interaction }\end{array}$ & AP-1 Member & Mechanism & Activity & Cell Type & References \\
\hline$C D 28$ & $\rightarrow$ (upregulates) & cJun & PI3K, JNK and ERK dependent & T-cell activation & & {$[42,60-63]$} \\
\hline ICOS & $\leftarrow$ (upregulates) & $\begin{array}{l}\text { Fra- } 2 \text { and } \\
\text { other AP-1 }\end{array}$ & $\begin{array}{l}\text { TCR/CD28 stimulation/ ICOS } \\
\text { promoter binding }\end{array}$ & $\begin{array}{c}\text { Expansion of several T } \\
\text { helper subsets and Tregs }\end{array}$ & T-cells & [77] \\
\hline $4-1 B B$ & $\leftarrow$ (upregulates) & $\mathrm{AP}-1$ & $\begin{array}{l}\text { 4-1BB promoter binding. MEK } \\
\text { and JNK dependent. }\end{array}$ & $\begin{array}{l}\text { Co-stimulation of T-cells } \\
\text { responses }\end{array}$ & T-cells & {$[79,80]$} \\
\hline$P D-1$ & $\rightarrow$ (upregulates) & BATF & & Inhibits T-cell function & $\begin{array}{l}\text { T-cells in chronic viral } \\
\text { infections }\end{array}$ & [85] \\
\hline$P D-1$ & $\leftarrow$ (upregulates) & c-Fos & PD-1 promoter binding & $\begin{array}{l}\text { Increased tumor burden } \\
\text { when expressed in } \\
\text { infiltrating T-cells }\end{array}$ & $\begin{array}{l}\text { T-cells in mouse } \\
\text { model of lung } \\
\text { carcinoma }\end{array}$ & [86] \\
\hline$P D-L 1$ & $\leftarrow$ (upregulates) & cJun, JunB & PD-L1 promoter binding & & EBV $(+)$ tumor cells & [91] \\
\hline$P D-L 1$ & $\leftarrow$ (upregulates) & cJun & MAPK dependent & & $\begin{array}{l}\text { BRAFi melanoma cell } \\
\text { lines }\end{array}$ & [92] \\
\hline$P D-L 1$ & $\leftarrow$ (upregulates) & cJun & $\begin{array}{l}\text { PD-L1 promoter binding. } \\
\text { MAPK dependent }\end{array}$ & & Lung carcinoma & [93] \\
\hline FOXP3 & $\rightarrow$ (downregulates) & cJun, cFos & JNK dependent & $\begin{array}{c}\text { Maintains } \\
\text { unresponsiveness of Tregs }\end{array}$ & $\begin{array}{l}\text { Natural occurring } \\
\text { Tregs }\end{array}$ & [110] \\
\hline FOXP3 & $\leftarrow$ (upregulates) & cJun, cFos & $\begin{array}{c}\text { FOXP3 promoter binding. JNK } \\
\text { dependent }\end{array}$ & $\begin{array}{c}\text { Controls FOXP3 promoter } \\
\text { activity }\end{array}$ & Sepsis model of Tregs & [111] \\
\hline FOXP3 & $\leftarrow$ (upregulates) & $\mathrm{AP}-1$ & $\begin{array}{c}\text { TGFb-induced FOXP3 } \\
\text { promoter binding. MAPK } \\
\text { dependent }\end{array}$ & $\begin{array}{l}\text { Controls FOXP3 } \\
\text { transcriptional activity }\end{array}$ & Tregs & [113] \\
\hline FOXP3 & $\leftarrow$ (downregulates) & BATF3 & FOXP3 promoter binding & $\begin{array}{l}\text { Transcriptional suppressor } \\
\text { of differentiation of Tregs }\end{array}$ & Tregs & [114] \\
\hline ICOS, CTLA-4 & $\leftarrow$ (upregulate) & JunB & IRF4 dependent & $\begin{array}{l}\text { Loss of JunB in Tregs } \\
\text { results in multi-organ } \\
\text { autoimmunity }\end{array}$ & Tregs & [118] \\
\hline
\end{tabular}


In lung and EBV(+) tumors such as Hodgkin's lymphoma and nasopharyngeal carcinoma, members of the AP-1 family (cJun and JunB) were found to bind the PD-L1 promoter and induce its expression in a MAPK dependent manner [90-93]. In a murine model of lung cancer, c-fos overexpression in T-cells, exacerbated tumor progression and led to higher mortality rates compared to control mice. C-Fos forms complexes with cJun and JunB and bind to PD-1 promoter and thus upregulates PD-1 expression in infiltrating T-cells, resulting in attenuated anti-tumor response in this animal model [86]. Moreover, in chronic viral infections, PD-1 expression in T-cells abrogates T-cell proliferation and cytokine expression leading to exhaustion phenotype, through upregulation of the AP-1 protein, BATF [85]. Lastly, studies have demonstrated that CTLA-4 ligation in T-cells disrupts CD28/TCR-dependent signaling and more specifically MAPK (ERK and JNK) activation leading to immune checkpoint inhibition via marked decrease in AP-1 binding activity [101-103]. In Tregs, several studies have provided evidence that AP-1 proteins physically bind at regulatory regions of FOXP3 promoter and facilitate its transactivation $[108,109,111]$. TCR-TGF- $\beta$ signaling in Tregs was also shown to induce FOXP3 in a MAPK dependent manner. MAPK downstream cascade leads to the AP-1 activation and transactivation of FOXP3 [113]. Conversely, induction of the AP-1 transcription factor BATF- 3 by OX40 ligation in Tregs, negatively regulates FOXP3 transcription by physically attaching to the FOXP3 promoter and attenuated its expression [117].

Author Contributions: V.A. did the bibliographic search, wrote the article including tables and figures. V.L. contributed in writing a part of the review. G.Z.R. provided guidance for writing and revising the manuscript and critically edited the article in its initial and final forms. F.X.C. supervised the entire work and edited the final draft. All authors approved the content of the manuscript.

Funding: This research received no external funding.

Conflicts of Interest: All authors declare no conflict of interest.

\section{References}

1. Restifo, N.P.; Smyth, M.J.; Snyder, A. Acquired resistance to immunotherapy and future challenges. Nat. Rev. Cancer 2016, 16, 121. [CrossRef] [PubMed]

2. Pardoll, D.M. The blockade of immune checkpoints in cancer immunotherapy. Nat. Rev. Cancer 2012, 12, 252-264. [CrossRef] [PubMed]

3. Wei, S.C.; Duffy, C.R.; Allison, J.P. Fundamental mechanisms of immune checkpoint blockade therapy. Cancer Discov. 2018, 8, 1069-1086. [CrossRef] [PubMed]

4. Feng, Y.; Roy, A.; Masson, E.; Chen, T.T.; Humphrey, R.; Weber, J.S. Exposure-response relationships of the efficacy and safety of ipilimumab in patients with advanced melanoma. Clin. Cancer Res. 2013, 19, 3977-3986. [CrossRef] [PubMed]

5. Jenkins, R.W.; Barbie, D.A.; Flaherty, K.T. Mechanisms of resistance to immune checkpoint inhibitors. Br. J. Cancer 2018, 118, 9. [CrossRef] [PubMed]

6. Sharma, P.; Hu-Lieskovan, S.; Wargo, J.A.; Ribas, A. Primary, adaptive, and acquired resistance to cancer immunotherapy. Cell 2017, 168, 707-723. [CrossRef] [PubMed]

7. Pitt, J.M.; Vetizou, M.; Daillere, R.; Roberti, M.P.; Yamazaki, T.; Routy, B.; Lepage, P.; Boneca, I.G.; Chamaillard, M.; Kroemer, G.; et al. Resistance mechanisms to immune-checkpoint blockade in cancer: tumor-intrinsic and-extrinsic factors. Immunity 2016, 44, 1255-1269. [CrossRef] [PubMed]

8. Liu, C.; Peng, W.; Xu, C.; Lou, Y.; Zhang, M.; Wargo, J.A.; Chen, J.Q.; Li, H.S.; Watowich, S.S.; Yang, Y.; et al. BRAF inhibition increases tumor infiltration by $\mathrm{T}$ cells and enhances the antitumor activity of adoptive immunotherapy in mice. Clin. Cancer Res. 2013, 19, 393-403. [CrossRef]

9. Peng, W.; Chen, J.Q.; Liu, C.; Malu, S.; Creasy, C.; Tetzlaff, M.T.; Xu, C.; McKenzie, J.A.; Zhang, C.; Liang, X.; et al. Loss of PTEN promotes resistance to T cell-mediated immunotherapy. Cancer Discov. 2016, 6, 202-216. [CrossRef]

10. Parsa, A.T.; Waldron, J.S.; Panner, A.; Crane, C.A.; Parney, I.F.; Barry, J.J.; Cachola, K.E.; Murray, J.C.; Tihan, T.; Jensen, M.C.; et al. Loss of tumor suppressor PTEN function increases B7-H1 expression and immunoresistance in glioma. Nat. Med. 2007, 13, 84-88. [CrossRef] 
11. Spranger, S.; Bao, R.; Gajewski, T.F. Melanoma-intrinsic beta-catenin signalling prevents anti-tumour immunity. Nature 2015, 523, 231-235. [CrossRef] [PubMed]

12. Kono, M.; Dunn, I.S.; Durda, P.J.; Butera, D.; Rose, L.B.; Haggerty, T.J.; Benson, E.M.; Kurnick, J.T. Role of the mitogen-activated protein kinase signaling pathway in the regulation of human melanocytic antigen expression. Mol. Cancer Res. 2006, 4, 779-792. [CrossRef] [PubMed]

13. Boni, A.; Cogdill, A.P.; Dang, P.; Udayakumar, D.; Njauw, C.N.; Sloss, C.M.; Ferrone, C.R.; Flaherty, K.T.; Lawrence, D.P.; Fisher, D.E.; et al. Selective BRAFV600E inhibition enhances T-cell recognition of melanoma without affecting lymphocyte function. Cancer Res. 2010, 70, 5213-5219. [CrossRef] [PubMed]

14. Frederick, D.T.; Piris, A.; Cogdill, A.P.; Cooper, Z.A.; Lezcano, C.; Ferrone, C.R.; Mitra, D.; Boni, A.; Newton, L.P.; Liu, C.; et al. BRAF inhibition is associated with enhanced melanoma antigen expression and a more favorable tumor microenvironment in patients with metastatic melanoma. Clin. Cancer Res. 2013, 19, 1225-1231. [CrossRef] [PubMed]

15. Mimura, K.; Shiraishi, K.; Mueller, A.; Izawa, S.; Kua, L.F.; So, J.; Yong, W.P.; Fujii, H.; Seliger, B.; Kiessling, R.; et al. The MAPK pathway is a predominant regulator of HLA-A expression in esophageal and gastric cancer. J. Immunol. 2013, 191, 6261-6272. [CrossRef]

16. Brea, E.J.; Oh, C.Y.; Manchado, E.; Budhu, S.; Gejman, R.S.; Mo, G.; Mondello, P.; Han, J.E.; Jarvis, C.A.; Ulmert, D.; et al. Kinase regulation of human MHC class I molecule expression on cancer cells. Cancer Immunol. Res. 2016, 4, 936-947. [CrossRef] [PubMed]

17. Ebert, P.J.R.; Cheung, J.; Yang, Y.; McNamara, E.; Hong, R.; Moskalenko, M.; Gould, S.E.; Maecker, H.; Irving, B.A.; Kim, J.M.; et al. MAP kinase inhibition promotes T Cell and anti-tumor activity in combination with PD-L1 checkpoint blockade. Immunity 2016, 44, 609-621. [CrossRef]

18. Pelster, M.S.; Amaria, R.N. Combined targeted therapy and immunotherapy in melanoma: A review of the impact on the tumor microenvironment and outcomes of early clinical trials. Ther. Adv. Med. Oncol. 2019, 11, 1758835919830826. [CrossRef]

19. Tawbi, H.A.-H.; Amaria, R.N.; Glitza, I.C.; Milton, D.; Hwu, W.-J.; Patel, S.P.; Wong, M.K.K.; Yee, C.; Woodman, S.E.; McQuade, J.L.; et al. Safety and preliminary activity data from a single center phase II study of triplet combination of nivolumab (N) with dabrafenib (D) and trametinib (T) [trident] in patients (Pts) with BRAF-mutated metastatic melanoma (MM). J. Clin. Oncol. 2018, 36, 9560. [CrossRef]

20. Dummer, R.; Fernández, A.M.A.; Hansson, J.; Larkin, J.M.G.; Long, G.V.; Gasal, E.; Kaper, M.; Upalawanna, A.; Mookerjee, B.; Atkinson, V. Preliminary findings from part 1 of COMBI-i: A phase III study of anti-PD-1 antibody PDR001 combined with dabrafenib (D) and trametinib (T) in previously untreated patients (pts) with advanced BRAF V600-mutant melanoma. J. Clin. Oncol. 2018, 36, 189. [CrossRef]

21. Shaulian, E.; Karin, M. AP-1 as a regulator of cell life and death. Nat. Cell Biol. 2002, 4, E131-E136. [CrossRef] [PubMed]

22. Foletta, V.C.; Segal, D.H.; Cohen, D.R. Transcriptional regulation in the immune system: All roads lead to AP-1. J. Leukoc. Biol. 1998, 63, 139-152. [CrossRef] [PubMed]

23. Wagner, E.F.; Eferl, R. Fos/AP-1 proteins in bone and the immune system. Immunol. Rev. 2005, 208, $126-140$. [CrossRef] [PubMed]

24. Karin, M. The regulation of AP-1 activity by mitogen-activated protein kinases. J. Biol. Chem. 1995, 270, 16483-16486. [CrossRef] [PubMed]

25. Lee, W.; Haslinger, A.; Karin, M.; Tjian, R. Activation of transcription by two factors that bind promoter and enhancer sequences of the human metallothionein gene and SV40. Nature 1987, 325, 368-372. [CrossRef] [PubMed]

26. Angel, P.; Imagawa, M.; Chiu, R.; Stein, B.; Imbra, R.J.; Rahmsdorf, H.J.; Jonat, C.; Herrlich, P.; Karin, M. Phorbol ester-inducible genes contain a common cis element recognized by a TPA-modulated trans-acting factor. Cell 1987, 49, 729-739. [CrossRef]

27. Eferl, R.; Wagner, E.F. AP-1: A double-edged sword in tumorigenesis. Nat. Rev. Cancer 2003, 3, 859. [CrossRef] [PubMed]

28. Nakabeppu, Y.; Nathans, D. The basic region of Fos mediates specific DNA binding. EMBO J. 1989, 8 , 3833-3841. [CrossRef] [PubMed]

29. Zerial, M.; Toschi, L.; Ryseck, R.P.; Schuermann, M.; Muller, R.; Bravo, R. The product of a novel growth factor activated gene, fos $\mathrm{B}$, interacts with JUN proteins enhancing their DNA binding activity. EMBO J. 1989, 8, 805-813. [CrossRef] 
30. Halazonetis, T.D.; Georgopoulos, K.; Greenberg, M.E.; Leder, P. C-Jun dimerizes with itself and with c-Fos, forming complexes of different DNA binding affinities. Cell 1988, 55, 917-924. [CrossRef]

31. Chiu, R.; Angel, P.; Karin, M. Jun-B differs in its biological properties from, and is a negative regulator of, c-Jun. Cell 1989, 59, 979-986. [CrossRef]

32. Schutte, J.; Viallet, J.; Nau, M.; Segal, S.; Fedorko, J.; Minna, J. Jun-B inhibits and c-fos stimulates the transforming and trans-activating activities of c-jun. Cell 1989, 59, 987-997. [CrossRef]

33. Li, B.; Tournier, C.; Davis, R.J.; Flavell, R.A. Regulation of IL-4 expression by the transcription factor Jun-B during T helper cell differentiation. EMBO J. 1999, 18, 420-432. [CrossRef] [PubMed]

34. Behrens, A.; Sabapathy, K.; Graef, I.; Cleary, M.; Crabtree, G.R.; Wagner, E.F. Jun N-terminal kinase 2 modulates thymocyte apoptosis and $\mathrm{T}$ cell activation through c-Jun and nuclear factor of activated $\mathrm{T}$ cell (NF-AT). Proc. Natl. Acad. Sci. USA 2001, 98, 1769-1774. [CrossRef] [PubMed]

35. Carrozza, M.L.; Jacobs, H.; Acton, D.; Verma, I.; Berns, A. Overexpression of the Fos B2 gene in thymocytes causes aberrant development of T cells and thymic epithelial cells. Oncogene 1997, 14, 1083-1091. [CrossRef] [PubMed]

36. Huse, M. The T-cell-receptor signaling network. J. Cell Sci. 2009, 122, 1269-1273. [CrossRef]

37. Linsley, P.S.; Ledbetter, J.A. The role of the CD28 receptor during T cell responses to antigen. Annu. Rev. Immunol. 1993, 11, 191-212. [CrossRef] [PubMed]

38. Smith-Garvin, J.E.; Koretzky, G.A.; Jordan, M.S. T cell activation. Annu. Rev. Immunol. 2009, 27, 591-619. [CrossRef]

39. Marais, R.; Wynne, J.; Treisman, R. The SRF accessory protein Elk-1 contains a growth factor-regulated transcriptional activation domain. Cell 1993, 73, 381-393. [CrossRef]

40. Hibi, M.; Lin, A.; Smeal, T.; Minden, A.; Karin, M. Identification of an oncoprotein- and UV-responsive protein kinase that binds and potentiates the c-Jun activation domain. Genes Dev. 1993, 7, 2135-2148. [CrossRef]

41. Spangler, B.; Vardimon, L.; Bosserhoff, A.K.; Kuphal, S. Post-transcriptional regulation controlled by E-cadherin is important for c-Jun activity in melanoma. Pigment. Cell Melanoma Res. 2011, 24, 148-164. [CrossRef] [PubMed]

42. Edmead, C.E.; Patel, Y.I.; Wilson, A.; Boulougouris, G.; Hall, N.D.; Ward, S.G.; Sansom, D.M. Induction of activator protein (AP)-1 and nuclear factor-kappaB by CD28 stimulation involves both phosphatidylinositol 3-kinase and acidic sphingomyelinase signals. J. Immunol. 1996, 157, 3290-3297. [PubMed]

43. Macian, F. NFAT proteins: Key regulators of T-cell development and function. Nat. Rev. Immunol. 2005, 5, 472. [CrossRef] [PubMed]

44. Macian, F.; Lopez-Rodriguez, C.; Rao, A. Partners in transcription: NFAT and AP-1. Oncogene 2001, 20, 2476-2489. [CrossRef] [PubMed]

45. McGuire, K.L.; Iacobelli, M. Involvement of Rel, Fos, and Jun proteins in binding activity to the IL-2 promoter CD28 response element/AP-1 sequence in human T cells. J. Immunol. 1997, 159, 1319-1327. [PubMed]

46. Schwartz, R.H. T cell anergy. Annu. Rev. Immunol. 2003, 21, 305-334. [CrossRef] [PubMed]

47. Wherry, E.J.; Kurachi, M. Molecular and cellular insights into T cell exhaustion. Nat. Rev. Immunol. 2015, 15, 486-499. [CrossRef]

48. Martinez, G.J.; Pereira, R.M.; Aijo, T.; Kim, E.Y.; Marangoni, F.; Pipkin, M.E.; Togher, S.; Heissmeyer, V.; Zhang, Y.C.; Crotty, S.; et al. The transcription factor NFAT promotes exhaustion of activated CD8(+) T cells. Immunity 2015, 42, 265-278. [CrossRef]

49. Macian, F.; Garcia-Cozar, F.; Im, S.H.; Horton, H.F.; Byrne, M.C.; Rao, A. Transcriptional mechanisms underlying lymphocyte tolerance. Cell 2002, 109, 719-731. [CrossRef]

50. Wherry, E.J.; Ha, S.J.; Kaech, S.M.; Haining, W.N.; Sarkar, S.; Kalia, V.; Subramaniam, S.; Blattman, J.N.; Barber, D.L.; Ahmed, R. Molecular signature of CD8+ T cell exhaustion during chronic viral infection. Immunity 2007, 27, 670-684. [CrossRef]

51. Fields, P.E.; Gajewski, T.F.; Fitch, F.W. Blocked Ras activation in anergic CD4+ T cells. Science 1996, 271, 1276-1278. [CrossRef] [PubMed]

52. Li, W.; Whaley, C.D.; Mondino, A.; Mueller, D.L. Blocked signal transduction to the ERK and JNK protein kinases in anergic CD4+ T cells. Science 1996, 271, 1272-1276. [CrossRef] [PubMed]

53. Mognol, G.P.; González-Avalos, E.; Ghosh, S.; Spreafico, R.; Gudlur, A.; Rao, A.; Damoiseaux, R.; Hogan, P.G. Targeting the NFAT: AP-1 transcriptional complex on DNA with a small-molecule inhibitor. Proc. Natl. Acad. Sci. USA 2019, 116, 9959-9968. [PubMed] 
54. Rizvi, N.A.; Mazieres, J.; Planchard, D.; Stinchcombe, T.E.; Dy, G.K.; Antonia, S.J.; Horn, L.; Lena, H.; Minenza, E.; Mennecier, B.; et al. Activity and safety of nivolumab, an anti-PD-1 immune checkpoint inhibitor, for patients with advanced, refractory squamous non-small-cell lung cancer (CheckMate 063): A phase 2, single-arm trial. Lancet Oncol. 2015, 16, 257-265. [CrossRef]

55. Robert, C.; Long, G.V.; Brady, B.; Dutriaux, C.; Maio, M.; Mortier, L.; Hassel, J.C.; Rutkowski, P.; McNeil, C.; Kalinka-Warzocha, E.; et al. Nivolumab in previously untreated melanoma without BRAF mutation. N. Engl. J. Med. 2015, 372, 320-330. [CrossRef] [PubMed]

56. Ansell, S.M.; Lesokhin, A.M.; Borrello, I.; Halwani, A.; Scott, E.C.; Gutierrez, M.; Schuster, S.J.; Millenson, M.M.; Cattry, D.; Freeman, G.J.; et al. PD-1 blockade with nivolumab in relapsed or refractory Hodgkin's lymphoma. N. Engl. J. Med. 2015, 372, 311-319. [CrossRef] [PubMed]

57. Chen, L.; Flies, D.B. Molecular mechanisms of T cell co-stimulation and co-inhibition. Nat. Rev. Immunol. 2013, 13, 227-242. [CrossRef] [PubMed]

58. Gross, J.A.; St John, T.; Allison, J.P. The murine homologue of the T lymphocyte antigen CD28. Molecular cloning and cell surface expression. J. Immunol. 1990, 144, 3201-3210. [PubMed]

59. Shahinian, A.; Pfeffer, K.; Lee, K.P.; Kundig, T.M.; Kishihara, K.; Wakeham, A.; Kawai, K.; Ohashi, P.S.; Thompson, C.B.; Mak, T.W. Differential T cell costimulatory requirements in CD28-deficient mice. Science 1993, 261, 609-612. [CrossRef] [PubMed]

60. Granelli-Piperno, A.; Nolan, P. Nuclear transcription factors that bind to elements of the IL-2 promoter. Induction requirements in primary human T cells. J. Immunol. 1991, 147, 2734-2739. [PubMed]

61. Rincon, M.; Flavell, R.A. AP-1 transcriptional activity requires both T-cell receptor-mediated and co-stimulatory signals in primary T lymphocytes. EMBO J. 1994, 13, 4370-4381. [CrossRef] [PubMed]

62. Su, B.; Jacinto, E.; Hibi, M.; Kallunki, T.; Karin, M.; Ben-Neriah, Y. JNK is involved in signal integration during costimulation of T lymphocytes. Cell 1994, 77, 727-736. [CrossRef]

63. Chatta, G.S.; Spies, A.G.; Chang, S.; Mize, G.J.; Linsley, P.S.; Ledbetter, J.A.; Morris, D.R. Differential regulation of proto-oncogenes c-jun and c-fos in T lymphocytes activated through CD28. J. Immunol. 1994, 153, 5393-5401. [PubMed]

64. Janardhan, S.V.; Praveen, K.; Marks, R.; Gajewski, T.F. Evidence implicating the Ras pathway in multiple CD28 costimulatory functions in CD4+ T cells. PLoS ONE 2011, 6, e24931. [CrossRef] [PubMed]

65. Li, W.; Whaley, C.D.; Bonnevier, J.L.; Mondino, A.; Martin, M.E.; Aagaard-Tillery, K.M.; Mueller, D.L. CD28 signaling augments Elk-1-dependent transcription at the c-fos gene during antigen stimulation. J. Immunol. 2001, 167, 827-835. [CrossRef] [PubMed]

66. Van Kooten, C.; Banchereau, J. Functions of CD40 on B cells, dendritic cells and other cells. Curr. Opin. Immunol. 1997, 9, 330-337. [CrossRef]

67. Elgueta, R.; Benson, M.J.; de Vries, V.C.; Wasiuk, A.; Guo, Y.; Noelle, R.J. Molecular mechanism and function of CD40/CD40L engagement in the immune system. Immunol. Rev. 2009, 229, 152-172. [CrossRef]

68. Bishop, G.A.; Moore, C.R.; Xie, P.; Stunz, L.L.; Kraus, Z.J. TRAF proteins in CD40 signaling. Adv. Exp. Med. Biol. 2007, 597, 131-151. [CrossRef]

69. Georgopoulos, N.T.; Steele, L.P.; Thomson, M.J.; Selby, P.J.; Southgate, J.; Trejdosiewicz, L.K. A novel mechanism of CD40-induced apoptosis of carcinoma cells involving TRAF3 and JNK/AP-1 activation. Cell Death Differ. 2006, 13, 1789-1801. [CrossRef]

70. Tsytsykova, A.V.; Tsitsikov, E.N.; Geha, R.S. The CD40L promoter contains nuclear factor of activated T cells-binding motifs which require AP-1 binding for activation of transcription. J. Biol. Chem. 1996, 271, 3763-3770. [CrossRef]

71. Afford, S.C.; Ahmed-Choudhury, J.; Randhawa, S.; Russell, C.; Youster, J.; Crosby, H.A.; Eliopoulos, A.; Hubscher, S.G.; Young, L.S.; Adams, D.H. CD40 activation-induced, Fas-dependent apoptosis and NF-kappaB/AP-1 signaling in human intrahepatic biliary epithelial cells. FASEB J. 2001, 15, 2345-2354. [CrossRef] [PubMed]

72. Baccam, M.; Woo, S.Y.; Vinson, C.; Bishop, G.A. CD40-mediated transcriptional regulation of the IL-6 gene in B lymphocytes: Involvement of NF-kappa B, AP-1, and C/EBP. J. Immunol. 2003, 170, 3099-3108. [CrossRef] [PubMed]

73. Vanden Bush, T.J.; Bishop, G.A. TLR7 and CD40 cooperate in IL-6 production via enhanced JNK and AP-1 activation. Eur. J. Immunol. 2008, 38, 400-409. [CrossRef] [PubMed] 
74. D'Aversa, T.G.; Eugenin, E.A.; Berman, J.W. CD40-CD40 ligand interactions in human microglia induce CXCL8 (interleukin-8) secretion by a mechanism dependent on activation of ERK1/2 and nuclear translocation of nuclear factor-kappaB (NFkappaB) and activator protein-1 (AP-1). J. Neurosci. Res. 2008, 86, 630-639. [CrossRef] [PubMed]

75. Hutloff, A.; Dittrich, A.M.; Beier, K.C.; Eljaschewitsch, B.; Kraft, R.; Anagnostopoulos, I.; Kroczek, R.A. ICOS is an inducible T-cell co-stimulator structurally and functionally related to CD28. Nature 1999, 397, 263-266. [CrossRef] [PubMed]

76. Coyle, A.J.; Lehar, S.; Lloyd, C.; Tian, J.; Delaney, T.; Manning, S.; Nguyen, T.; Burwell, T.; Schneider, H.; Gonzalo, J.A.; et al. The CD28-related molecule ICOS is required for effective T cell-dependent immune responses. Immunity 2000, 13, 95-105. [CrossRef]

77. Watanabe, M.; Nakajima, S.; Ohnuki, K.; Ogawa, S.; Yamashita, M.; Nakayama, T.; Murakami, Y.; Tanabe, K.; Abe, R. AP-1 is involved in ICOS gene expression downstream of TCR/CD28 and cytokine receptor signaling. Eur. J. Immunol. 2012, 42, 1850-1862. [CrossRef]

78. Kim, J.O.; Kim, H.W.; Baek, K.M.; Kang, C.Y. NF-kappaB and AP-1 regulate activation-dependent CD137 (4-1BB) expression in T cells. FEBS Lett. 2003, 541, 163-170. [CrossRef]

79. Kwon, B.S.; Kozak, C.A.; Kim, K.K.; Pickard, R.T. Genomic organization and chromosomal localization of the T-cell antigen 4-1BB. J. Immunol. 1994, 152, 2256-2262.

80. Kim, J.D.; Kim, C.H.; Kwon, B.S. Regulation of mouse 4-1BB expression: Multiple promoter usages and a splice variant. Mol. Cells 2011, 31, 141-149. [CrossRef]

81. Arasanz, H.; Gato-Cañas, M.; Zuazo, M.; Ibañez-Vea, M.; Breckpot, K.; Kochan, G.; Escors, D. PD1 signal transduction pathways in T cells. Oncotarget 2017, 8, 51936-51945. [CrossRef] [PubMed]

82. Sheppard, K.A.; Fitz, L.J.; Lee, J.M.; Benander, C.; George, J.A.; Wooters, J.; Qiu, Y.; Jussif, J.M.; Carter, L.L.; Wood, C.R.; et al. PD-1 inhibits T-cell receptor induced phosphorylation of the ZAP70/CD3zeta signalosome and downstream signaling to PKCtheta. FEBS Lett. 2004, 574, 37-41. [CrossRef] [PubMed]

83. Hui, E.; Cheung, J.; Zhu, J.; Su, X.; Taylor, M.J.; Wallweber, H.A.; Sasmal, D.K.; Huang, J.; Kim, J.M.; Mellman, I.; et al. T cell costimulatory receptor CD28 is a primary target for PD-1-mediated inhibition. Science 2017, 355, 1428-1433. [CrossRef] [PubMed]

84. Francisco, L.M.; Salinas, V.H.; Brown, K.E.; Vanguri, V.K.; Freeman, G.J.; Kuchroo, V.K.; Sharpe, A.H. PD-L1 regulates the development, maintenance, and function of induced regulatory T cells. J. Exp. Med. 2009, 206, 3015-3029. [CrossRef] [PubMed]

85. Quigley, M.; Pereyra, F.; Nilsson, B.; Porichis, F.; Fonseca, C.; Eichbaum, Q.; Julg, B.; Jesneck, J.L.; Brosnahan, K.; Imam, S.; et al. Transcriptional analysis of HIV-specific CD8+ T cells shows that PD-1 inhibits T cell function by upregulating BATF. Nat. Med. 2010, 16, 1147-1151. [CrossRef] [PubMed]

86. Xiao, G.; Deng, A.; Liu, H.; Ge, G.; Liu, X. Activator protein 1 suppresses antitumor T-cell function via the induction of programmed death 1. Proc. Natl. Acad. Sci. USA 2012, 109, 15419-15424. [CrossRef]

87. Chen, L. Co-inhibitory molecules of the B7-CD28 family in the control of T-cell immunity. Nat. Rev. Immunol. 2004, 4, 336-347. [CrossRef] [PubMed]

88. Zerdes, I.; Matikas, A.; Bergh, J.; Rassidakis, G.Z.; Foukakis, T. Genetic, transcriptional and post-translational regulation of the programmed death protein ligand 1 in cancer: Biology and clinical correlations. Oncogene 2018, 37, 4639-4661. [CrossRef]

89. Mathas, S.; Hinz, M.; Anagnostopoulos, I.; Krappmann, D.; Lietz, A.; Jundt, F.; Bommert, K.; Mechta-Grigoriou, F.; Stein, H.; Dorken, B.; et al. Aberrantly expressed c-Jun and JunB are a hallmark of Hodgkin lymphoma cells, stimulate proliferation and synergize with NF-kappa B. EMBO J. 2002, 21, 4104-4113. [CrossRef]

90. Green, M.R.; Rodig, S.; Juszczynski, P.; Ouyang, J.; Sinha, P.; O’Donnell, E.; Neuberg, D.; Shipp, M.A. Constitutive AP-1 activity and EBV infection induce PD-L1 in Hodgkin lymphomas and posttransplant lymphoproliferative disorders: Implications for targeted therapy. Clin. Cancer Res. 2012, 18, 1611-1618. [CrossRef]

91. Fang, W.; Zhang, J.; Hong, S.; Zhan, J.; Chen, N.; Qin, T.; Tang, Y.; Zhang, Y.; Kang, S.; Zhou, T.; et al. EBV-driven LMP1 and IFN-gamma up-regulate PD-L1 in nasopharyngeal carcinoma: Implications for oncotargeted therapy. Oncotarget 2014, 5, 12189-12202. [CrossRef] [PubMed] 
92. Jiang, X.; Zhou, J.; Giobbie-Hurder, A.; Wargo, J.; Hodi, F.S. The activation of MAPK in melanoma cells resistant to BRAF inhibition promotes PD-L1 expression that is reversible by MEK and PI3K inhibition. Clin. Cancer Res. 2013, 19, 598-609. [CrossRef] [PubMed]

93. Sumimoto, H.; Takano, A.; Teramoto, K.; Daigo, Y. RAS-mitogen-activated protein kinase signal is required for enhanced PD-L1 expression in human lung cancers. PLoS ONE 2016, 11, e0166626. [CrossRef] [PubMed]

94. Pauken, K.E.; Sammons, M.A.; Odorizzi, P.M.; Manne, S.; Godec, J.; Khan, O.; Drake, A.M.; Chen, Z.; Sen, D.R.; Kurachi, M.; et al. Epigenetic stability of exhausted T cells limits durability of reinvigoration by PD-1 blockade. Science 2016, 354, 1160-1165. [CrossRef] [PubMed]

95. Collins, A.V.; Brodie, D.W.; Gilbert, R.J.; Iaboni, A.; Manso-Sancho, R.; Walse, B.; Stuart, D.I.; van der Merwe, P.A.; Davis, S.J. The interaction properties of costimulatory molecules revisited. Immunity 2002, 17, 201-210. [CrossRef]

96. Waterhouse, P.; Penninger, J.M.; Timms, E.; Wakeham, A.; Shahinian, A.; Lee, K.P.; Thompson, C.B.; Griesser, H.; Mak, T.W. Lymphoproliferative disorders with early lethality in mice deficient in Ctla-4. Science 1995, 270, 985-988. [CrossRef] [PubMed]

97. Rudd, C.E.; Taylor, A.; Schneider, H. CD28 and CTLA-4 coreceptor expression and signal transduction. Immunol. Rev. 2009, 229, 12-26. [CrossRef]

98. Wing, K.; Onishi, Y.; Prieto-Martin, P.; Yamaguchi, T.; Miyara, M.; Fehervari, Z.; Nomura, T.; Sakaguchi, S. CTLA-4 control over Foxp3+ regulatory T cell function. Science 2008, 322, 271-275. [CrossRef]

99. Takahashi, T.; Tagami, T.; Yamazaki, S.; Uede, T.; Shimizu, J.; Sakaguchi, N.; Mak, T.W.; Sakaguchi, S. Immunologic self-tolerance maintained by CD25(+) CD4(+) regulatory T cells constitutively expressing cytotoxic T lymphocyte-associated antigen 4. J. Exp. Med. 2000, 192, 303-310. [CrossRef]

100. Peggs, K.S.; Quezada, S.A.; Chambers, C.A.; Korman, A.J.; Allison, J.P. Blockade of CTLA-4 on both effector and regulatory $\mathrm{T}$ cell compartments contributes to the antitumor activity of anti-CTLA-4 antibodies. J. Exp. Med. 2009, 206, 1717-1725. [CrossRef]

101. Calvo, C.R.; Amsen, D.; Kruisbeek, A.M. Cytotoxic T lymphocyte antigen 4 (CTLA-4) interferes with extracellular signal-regulated kinase (ERK) and Jun NH2-terminal kinase (JNK) activation, but does not affect phosphorylation of T cell receptor zeta and ZAP70. J. Exp. Med. 1997, 186, 1645-1653. [CrossRef] [PubMed]

102. Olsson, C.; Riesbeck, K.; Dohlsten, M.; Michaelsson, E. CTLA-4 ligation suppresses CD28-induced NF-kappaB and AP-1 activity in mouse T cell blasts. J. Biol. Chem. 1999, 274, 14400-14405. [CrossRef] [PubMed]

103. Fraser, J.H.; Rincon, M.; McCoy, K.D.; Le Gros, G. CTLA4 ligation attenuates AP-1, NFAT and NF-kappaB activity in activated T cells. Eur. J. Immunol. 1999, 29, 838-844. [CrossRef]

104. Sakaguchi, S.; Sakaguchi, N.; Asano, M.; Itoh, M.; Toda, M. Immunologic self-tolerance maintained by activated T cells expressing IL-2 receptor alpha-chains (CD25). Breakdown of a single mechanism of self-tolerance causes various autoimmune diseases. J. Immunol. 1995, 155, 1151-1164. [PubMed]

105. Hori, S.; Nomura, T.; Sakaguchi, S. Control of regulatory T cell development by the transcription factor Foxp3. Science 2003, 299, 1057-1061. [CrossRef] [PubMed]

106. Sakaguchi, S.; Yamaguchi, T.; Nomura, T.; Ono, M. Regulatory T cells and immune tolerance. Cell 2008, 133, 775-787. [CrossRef] [PubMed]

107. Tanaka, A.; Sakaguchi, S. Regulatory T cells in cancer immunotherapy. Cell Res. 2016, 27, 109. [CrossRef]

108. Mantel, P.Y.; Ouaked, N.; Ruckert, B.; Karagiannidis, C.; Welz, R.; Blaser, K.; Schmidt-Weber, C.B. Molecular mechanisms underlying FOXP3 induction in human T cells. J. Immunol. 2006, 176, 3593-3602. [CrossRef]

109. Ogawa, C.; Tone, Y.; Tsuda, M.; Peter, C.; Waldmann, H.; Tone, M. TGF-beta-mediated Foxp3 gene expression is cooperatively regulated by Stat5, Creb, and AP-1 through CNS2. J. Immunol. 2014, 192, 475-483. [CrossRef]

110. Lee, S.M.; Gao, B.; Fang, D. FoxP3 maintains Treg unresponsiveness by selectively inhibiting the promoter DNA-binding activity of AP-1. Blood 2008, 111, 3599-3606. [CrossRef]

111. Bao, R.; Hou, J.; Li, Y.; Bian, J.; Deng, X.; Zhu, X.; Yang, T. Adenosine promotes Foxp3 expression in Treg cells in sepsis model by activating JNK/AP-1 pathway. Am. J. Transl. Res. 2016, 8, 2284-2292. [PubMed]

112. Fantini, M.C.; Becker, C.; Monteleone, G.; Pallone, F.; Galle, P.R.; Neurath, M.F. Cutting edge: TGF-beta induces a regulatory phenotype in CD4+CD25- T cells through Foxp3 induction and down-regulation of Smad7. J. Immunol. 2004, 172, 5149-5153. [CrossRef] [PubMed] 
113. Xu, L.; Kitani, A.; Stuelten, C.; McGrady, G.; Fuss, I.; Strober, W. Positive and negative transcriptional regulation of the Foxp3 gene is mediated by access and binding of the Smad3 protein to enhancer I. Immunity 2010, 33, 313-325. [CrossRef] [PubMed]

114. Lee, W.; Kim, H.S.; Hwang, S.S.; Lee, G.R. The transcription factor Batf3 inhibits the differentiation of regulatory T cells in the periphery. Exp. Mol. Med. 2017, 49, e393. [CrossRef] [PubMed]

115. Hayatsu, N.; Miyao, T.; Tachibana, M.; Murakami, R.; Kimura, A.; Kato, T.; Kawakami, E.; Endo, T.A.; Setoguchi, R.; Watarai, H.; et al. Analyses of a mutant Foxp3 allele reveal BATF as a critical transcription factor in the differentiation and accumulation of tissue regulatory T cells. Immunity 2017, 47, 268-283. [CrossRef] [PubMed]

116. Croft, M. Control of immunity by the TNFR-related molecule OX40 (CD134). Annu. Rev. Immunol. 2010, 28, 57-78. [CrossRef] [PubMed]

117. Zhang, X.; Xiao, X.; Lan, P.; Li, J.; Dou, Y.; Chen, W.; Ishii, N.; Chen, S.; Xia, B.; Chen, K.; et al. OX40 costimulation inhibits Foxp3 expression and Treg induction via BATF3-dependent and independent mechanisms. Cell Rep. 2018, 24, 607-618. [CrossRef]

118. Koizumi, S.I.; Sasaki, D.; Hsieh, T.H.; Taira, N.; Arakaki, N.; Yamasaki, S.; Wang, K.; Sarkar, S.; Shirahata, H.; Miyagi, M.; et al. JunB regulates homeostasis and suppressive functions of effector regulatory T cells. Nat. Commun. 2018, 9, 5344. [CrossRef]

(C) 2019 by the authors. Licensee MDPI, Basel, Switzerland. This article is an open access article distributed under the terms and conditions of the Creative Commons Attribution (CC BY) license (http://creativecommons.org/licenses/by/4.0/). 